\title{
MUTUALISME SISTEMIK ANTARA GURU, SISWA DAN KURIKULUM DI SEKOLAH MENENGAH
}

\section{Oleh: Thaharuddin *}

\begin{abstract}
Siswa, guru dan kurikulum sering mendapat sorotan dalam dunia pendidikan. Unruh dam Alexander melihat bahwa inovasi pendidikan sering memberikan sasaran pada perbaikan ketiga unsur tersebut. Siswa mengalami dinamika sosial dan psikologi, yang secara kontekstual akan mempenganuhi bagaimana mendidik anak yang sebenaranya. Guru sebagai fasilitator pembelajaran di sekolah harus meningkatkan kemampuan profesional secara terus-menerus yang artinya secara kontekstual bagaimana melakukan pembelajaran yang sesuai dengan kebutuhan dan perkembangan siswa. Demikian juga kurikulum sebagai seperangkat acuan dalam pelaksanaan pendidikan harus mencerminkan kebutuhan siswa dengan segala kompleksitanya dalam kehidupan sosial, ilmu pengetahuan dan teknologi.
\end{abstract}

Kata Kunci: Mutualistme,Sistemik, Guru, Siswa, Kurikulum

\section{A. Pendahuluan}

Guru, siswa dan kurikulum merupakan komponen utama untuk berlangsungnya pendidikan di sekolah (UUSPN, 1989; Murgatroyad \&Mongan:1994). Dalam wacana pendidikan nasional aspek ini selalu menjadi bagian penting dari upaya untuk membangun dan meningkatkan kualitas pendidikan. Bahkan proses belajar mengajar di sekolah akan berlangsung secara baik manakala ketiga unsur ini berada dalam keserasian sehingga proses pembelajaran berlangsung secara lebih efektif. Akan tetapi ketiga hal ini akan memberikan bagian penting dari pelaksanaan pembelajaran manakala sinergisitas terbangun dalam suasana kondusif, yang tentunya masingmasing unsur ini menjadi bagian penting dari pendidikan nasional.

Dewasa ini, bahwa siswa, guru dan kurikulum sering mendapat sorotan dalam dunia pendidikan. Unruh dam Alexander melihat bahwa inovasi pendidikan sering memberikan sasaran pada perbaikan ketiga unsur tersebut. Siswa mengalami dinamika sosial dan psikologi, yang secara kontekstual akan mempengaruhi bagaimana mendidik anak yang sebenaranya. Guru sebagai fasilitator pembelajaran di sekolah harus meningkatkan kemampuan profesional (Mantja, 1998) secara terusmenerus yang artinya secara kontekstual bagaimana melakukan pembelajaran yang

- Penulis adalah dosen tetap Sekotah Tinggi Agama Islam Nogeri (STAW) Mataran dan juga Mahasíswa pada Program Pascasarjana thiversitas Berogama Jakarta 
sesuai dengan kebutuhan dan perkembangan siswa. Demikian juga kurikulum sebagai seperangkat acuan (Zais,1976) dalam pelaksanaan pendidikan harus mencerminkan kebutuhan siswa dengan segala kompleksitanya dalam kehidupan sosial, ilmu pengetahuan dan teknologi.

Dalam sistem pendidikan nasional bahwa guru sebagai komponen utama (Depdiknas, 2002)dalam pelaksanaan pendidikan. Tapi guru masih merupakan permasalahan pendidikan nasional yang pentinguntuk diperhatikan oleh pemerintah dan ahli pendidikan, terutama bagiamana untuk meningkatkan profesionalisme dan kualitasnya. Dari sederetan masalah yang dihadapi tentang guru dan tenaga kependidikan, yang paling mengemuka adalah tentang profesionalisme, kualitas dan kesejahteraan guru(BankDunia,1998 dalam Jalal \& Supriadi, 2001). Kegagalan dan keberhasilan pendidikan lalu kerap dikaitkan dengan kemampuan guru dalam mengarahkan proses pembelajaran di kelas atau proses pendidikan secara keseluruhan.

Siswa di sekolah menengah mempunyai tingkat perkembangan kepribadian dan sosial yang berada dimana pada masa transisi dari anak-anak ke remaja. Masa remaja di sekolah menengah menghadapi beberapa aspek utama perkembangan kejiwaan anak yaitu berkaitan dengan status sosial dan keragaman kemampuan kognisi yang akan mempengaruhi proses pendidikan di sekolah. Latar belakang sosial seperti keluarga, ekonomi masing-masing anak yang berbeda akan memberikan pengaruh pada prestasi anak di skeolah. Dengan kondisi perkembangan siswa pada masa ini maka proses pendidikan memerlukan kondisi kondusif agar perkembangan kemampuan kognitif, afektif dan psikomotorik siswa dapat mencapai tujuan yang diharapkan..

Kurikulum merupakan salah satu komponen utama pendidikan yang merupakan bagian penting dari terciptanya proses pendidikan di sekolah. Karena disinilah ditentukan tujuan, isi , metode dan aktivitas pembelajaran dan evalusai di kelas. Dalam UUSPN No.2 Th.1989 dijelaskan tentangkarakter kurikulum sekolah " Kurikulum disusun untuk mewujudkan tujuan pendidikan nasional dengan memperhtikan tahap perkembangan peserta didik dan kesesuaiannya dengan lingkungan, kebutuhan pembangunan nasional, perkembangan ilmu pengetahuan dan teknologi serta kesenian, sesuai dengan kesenian dan jenjang masing-masing satuan pendidikan (pasal, 37). Ini artinya, bahwa kurikulum hendaknya sangat mempertimbangkan aspek perkembangan peserta didik baik secara psikis dan fisik.

\section{B. Multi-Peran Guru di Sekolah}

Perkembangan dunia pendidikan di Indonesia sampai sekarang ini belum menggembirakan, yang memberikan indikasi pada masih rendahnya kualitas lulusan yang dihasilkan. Di mana bahwa lulusan di berbagai jenjang pendidikan tidak mempunyai kemampuanuntuk memberikan. Sementara kualitas pendidikan nasional 
masih jauh dari apa yang diharapkan semua pihak, yang tentunya tidak kalah pentingnnya untuk dibenahi adalah guru sebagai komponen utama pendidikan, guru sebagai tulang punggung pendidikan di sekolah. Untuk itulah perhatian terhadap guru, secara keseluruhan dari semua pihak yang berkepentingan terhadap peningkatan kualitas pendidikan perlu dilaksanakan. Peran dan fungsi guru di sekolah menjadi bagian penting dari upaya menciptakan tercapainya kualitas peroses pembelajaran yạng efektif.

Dalam era ilmu pengetahuan dan teknologi plus era globalisasi peran guru menjadi begitu kompleks, yang tentunya menuntut tingkat profesionalitas yang tinggi dalam melakukan proses pembelajaran. Ini di sebabkan karena sekolah menjadi tempat untuk menyiapkan kemampuan peserta didik yang memadai sesuai dengan kapasitas intelektualnya. Dalam buku SPTK-21 (Dipdiknas, 2002) tugas utama guru antara, yaitu: 1) Menjabarkan kebijakan dan landasan pendidikan dalam wujud perencanaan pembelajaran di kelas dan diluar kelas. 2) Mengaplikasikan komponenkomoponen pembelajaran sebagai suatu sistem dalam proses belajar mengajar.3) Melakukan komunikasi dalam komunitas profesi, sosial dan memfasilitasi pembelajaran masyarakat, 4) Mengelola kelas dengan pendekatan dan prosodur yang tepat dan relevan dengan karakteristik peserta didik, 5) Meneliti, mengembangkan, dan berinovasi di bidang pendidikan dan pembelajaran, dan mampu memanfaatkan hasilnya untuk pengembangan profesi.

Unruh dan Alxander (1970) mengukapkan peran guru yang semakin komplek meliputi ; 1) melakukan diagnosis; mampu menganslisis kondisi yang mempengaruhi pembelajaran siswa, 3)guru sebagai pembuat keputusan: terlibat dalam proses perencanaan dan pelaksanaan perubahan sistem sekolah, baik di tingkat lokal dan atau pun tingkat dinas, 3) guru yang koopratif; berkerja sama dengan siswa, staf dalam menyukseskan pembelajaran di sekolah, 4) peran strategis berupa keterlibatan dalam merencanakan dan mendisain perkembangan masing-masing siswa, membuat penilaian yang tepat, membuat perencanaan tentang speketrum kurikulum yang lebih luas, 5) guru sebagai manajer; menyiapkan sumber daya dan keahlian untuk melancarkan pembelajaran siswa, termasuk bantuan staf atau asistent dan sebagainya, 6) guru sebagai fasilitator proses pembelajaran melalui dinamika kelompok, belajar mandiri, penelitian, dan berbagai ekperimen bidang studi.7) guru sebagai pembimbing siswa untuk memotivasi kreativitas, dengan rasa empati, penuh kehangatan dan saling mengerti, 8) guru sebagai evaluator.

Lebih jauh dari itu bahwa Coley menjelaskan tentang tiga peran pembelajaran yang lebih laus sebagai pengambil keputusan di kelas, yang meliputi tugas pemebelajran, konseling dan pengelolaan. Disamping itu ada tiga fungsi guru yaitu merencanakan, melaksanakan dan mengevaluasi merupakan fungsi yang harus dijalankan dalam rangka mewujudkan proses pembelajaran di kelas. Keinginan untuk memberikan fungsi yang lebih luas kepada guru adalah untuk memberikan 
tingkat otonomi yang tinggi dalam memimpin proses belajar mengajar di kelas sehingga guru dapat membina anak dengan tingkat ketergantungan yang rendah terhadap guru.

Sodjiarto (1989) bahkan menemukan bahwa peranan guru di kelas harus diubah, bukan sebagai pemberi ceramah, yaitu guru hendaknya lebih mengutamakan kemampuan merencanakan, mengelola dan mengawasi terjadinya proses belajar mengajar antara siswa dikelas. Bahkan model "pemberi cermah" ini pernah dikritik Paoulu Fiere, sebagai model pendidikan gaya Bank, kernjang sampah, yang akan mematikan perkembangan siswa secara lebih luas. Karena peran guru sebagai pemberi informasi lebih merupakan upaya untuk mengebiri siswa dalam memahami peran pendidikan.

Semakin komplesknya perkembangan sosial kehidupan masyarakat tentu membawa pengaruh pada lingkungn sekolah, yang terkadang masalah siswa di keluarga atau ditengah masyarakat akan memberi dampak pada pencapaian prestasi anak di sekolah. Sehingga siswa yang datang ke sekolah tidak lepas dari apa yang terjadi pada lingkungan keluarga atau pun pribadinya, yang tentunya harus merupakan bagian penting yang harus dipahami oleh seorang guru. Dalam hal ini guru dituntut untuk mengetahui latar belakang siswa agar dapat mampu dibina perkembangannya secara maksimal. Guru tidak lagi memberikan informasi secarasepihak terhadap anak didik tetapi dituntut untuk menciptakan suasana agar anak dapat berkembang secara maksimal.

John Goodlad melakukan penelitian dengan publikasi penelitian "Behind The Classroom Door" menemukan bahwa kualitas pembelajaran akan sangat ditentukan oleh guru, manakala guru sudah memasuki ruang kelas serta pintu kelas tertutup maka kehidupan kelas akan menjadi wewenang dan tanggung jawab seorang guru. Guru merupakan sosok penting yang akan mewarnai suasana di dalam kehidupan kelas. Apakah guru mampu untuk memberikan dan membangun motivasi anak untuk berprestasi atau tidak? Disinilah guru diharapkan dapat membangun komunikasi yang efektif dalam rangka menciptakan hubungan interaktif antara guru danm siswa di kelas. Sehingga tuntutan guru profesional menjadi sangat penting untuk meningkatkan kualitas pembelajaran di sekolah.

Menurut Garys A Davis dan Margaret A Thomas (dikutip Suyanto, 2001) bahwa guru profesional mempunyai empat kemampuan, yaitu

pertama, kemampuan yang terkait dengan iklim belajar di kelas meliputi; 1) memiliki keterampilan interpersonal, khususnya kemampuan untuk menunjukkan empati, penghargaan kepada siswa dan ketulusan; 2) memiliki hubungsn baik dengan siswa; 3) mampu menerima, mengakui dan memperhatikan siswa secara tulus; 4) mampu menunjukkan minat dan antusias yang tinggi dalam mengajar; 5) mampu menciptakan atmosfer untuk tumbuhnya kerjasama dan kohesivitas antar dan dalam kelompok; 6) mampu melibatkan siswa dalam mengorganisasi dan merencanakan 
pembelajaran;7) mampu mendengarkan siswa dan menghargai hak siswa untuk berbicara dalam setip diskusi; 8) mampu meminimalkan friksi-friksi di kelas.

Kedua, kemampuan yang terkait dengan strategi manajemen pembelajaran meliputi; 1)memilki kemampuan untuk menangani siswa yang tidak mempunyai perhatian, suka menyela mengalihkan pembicaraan, dan mampu memberikan transisi substansi bahan ajar dalam proses pembelajaran; 2) mampu bertanya atau memberikan tugas yang memerlukan tingkat berpikir yag berbeda untuk semua siswa.

Ketiga, kemampuan yang terkait dengan umpan balik dan penguatan meliputi;1)mampu memberikan umpan balik yang positif atas respon siswa; 2)mampu meberikan respon yang bersifat membantu terhadap siswa yang lamban belajar; 3)mampu memberikan tindak lajut terhadap jawaban siswa yang kurang memuskan;4)mampu memberikan kemampuan profesional kepada siswa yang memerlukan bantuan.

Kempat, kemampuan yang terkait dengan peningakatan diri meliputi;1) mampu menerapkan kurikulum dan metode mengajar secara inovatif; 2) mampu memperluas dan menambah pengetahuan mengenai metode-metode pengajaran;3) mampu memanfaatkan perencanaan guru secara kelompok untuk menciptakan dan mengembangkan metode pengajaran yang relevan.

Dalam studi Basic Education Quality (EEP, 1992 dalam Suryadi,2001) bahwa guru profesional mempunyai karakteristik meliputi: 1) kemampuan profesional sebagai kemampuan intelegensia, sikap dan prestasi di bidang pekerjaan, 2) upaya profesional sebagai upaya untuk menaerapkan kemampuan profesional dalam proses belajar mengajar ,3) waktu yang dicurahkan untuk kegiatan profesional adalah intensitas waktu untuk mengajar, 4) akuntabilitas profesi manakala pekerjaan yang dilakukan dapan menjamin kesejahteraan hidupnya.

Kebutuhan akan seorang guru yang profesional merupakan tuntutan untuk meningkatkan kualitas proses pendidikan di sekolah. Ini artinya guru mempunyai ideologi yang kuat manakala berkaitan dengan pendidikan sebagai tempat mengembangkan profesinya dan tempat mengaktualisasikan diri, yang terkait dengan apa yang diharapka kepada siswa didikannya. Sementara ini, bahwa guru dianggap sebagai fungsi sosial yang kurang menguntungkan secara ekonomi, tapi secara moril mempunyai tanggung jawab yang sangat tinggi dalam meningkatkan perkembangan siswa. Sehingga sering kalibahwa kegagalan pendidikan, khususnya prestasi siswa yang kurang baik, dikaitkan dengan kualitas guru atau kegagalan seorang guru.

Posisi penting guru merupakan tanggung jawab profesi dan moril untuk meningkatkan upaya-upaya profesional dalam memimpin pembelajaran di kelas(Fullen,1993). Guru hendaknyan bersikap lebih demokratis di kelas. Kelas harus dikondisikan sebagai tempat untuk meningkatkan kemampuan intelegensia 


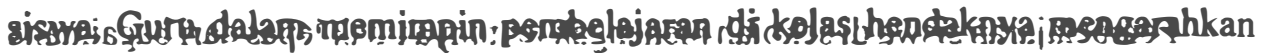
penkembanga giswa secara maksimal. Gurv hendaknya mampu untuk mernotivasi givova agar formotivași untuk menguasai pengetahuan yang diberikan, memeberikan motivasi untuk selalu meningkatkan prestesi belajar. Sejadagdongan upaya ini, maka

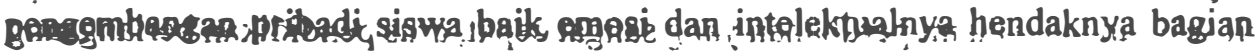

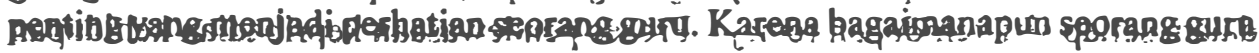

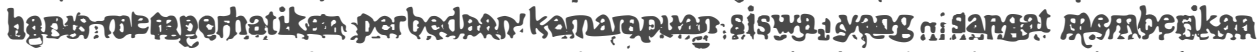

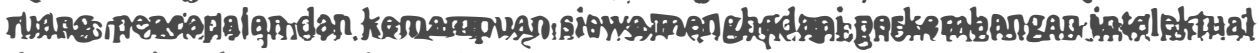

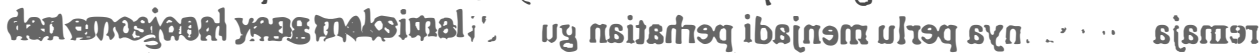

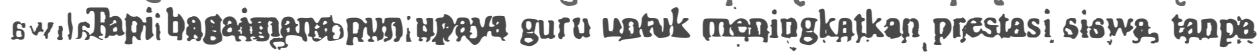

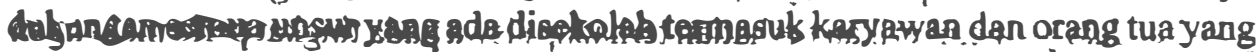

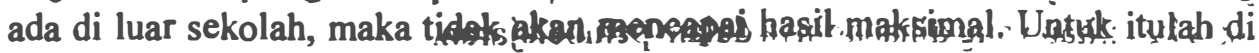

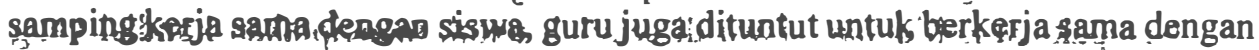

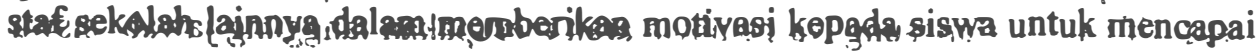

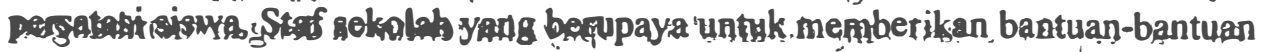

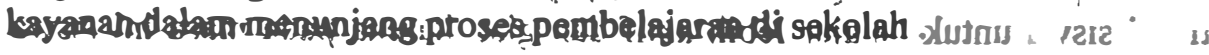

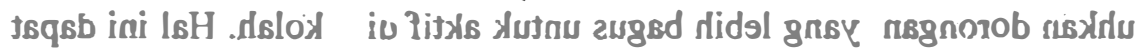

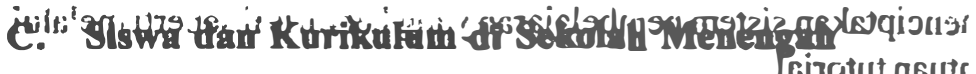

\section{muludizud эqib r Bislyd sib wese sesvison}

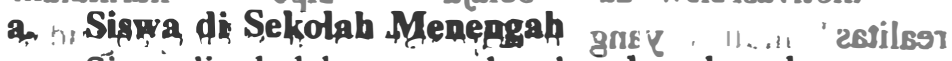

sir. Siswa dis sekolah menengah sedang berada pada, masas remaja, yang memiliki beperapa karakteristík perkembangan yang melipyti; apsek sosial masa remaja sudah mulai menyadari kehadirap lingkungan spsial sekitany a seperti keluarga,

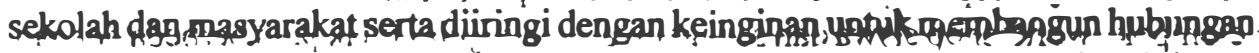

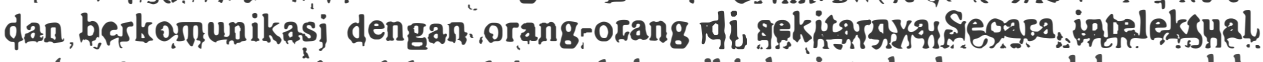

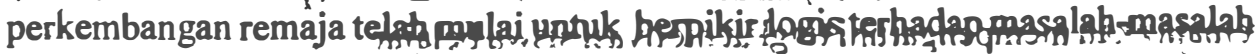
yang dihadapinya. Seçara emosi bahwa pada masạ remaja seprang te hah mengenal rasa cinta, rindu dan kinginan; untuk berkenalan, dengan lawan jenis. Pada mașa remaja, emosinya sangat sensetif, dan temperameptal realtififdalam menghadapi perristivasosial.

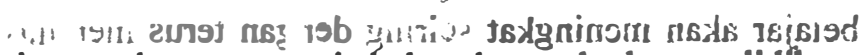

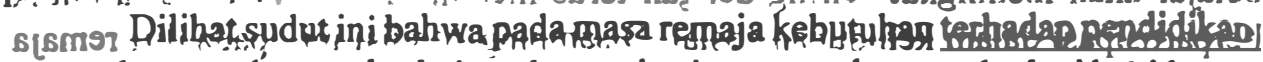

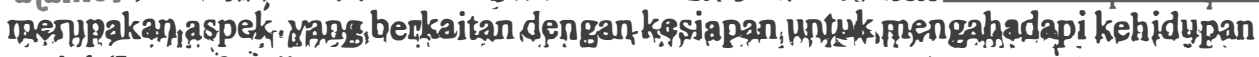

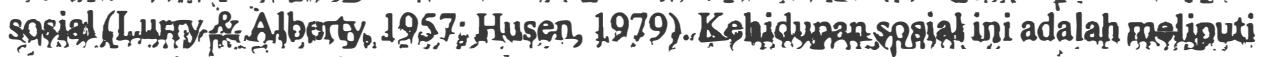
tanggung jawab sosial sebagai anggota masyarakat, daA, warga, pegara, \$erta

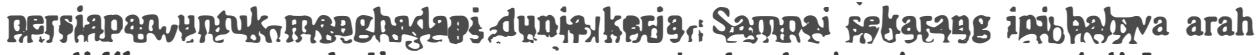
pendidikan menengah di, negara-negara maju dan berkentang seperti di Jepang,

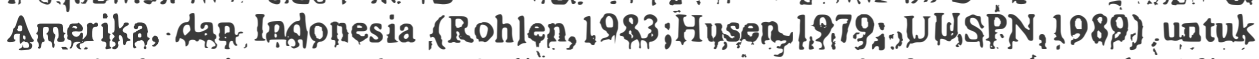

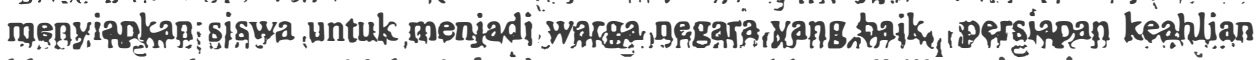

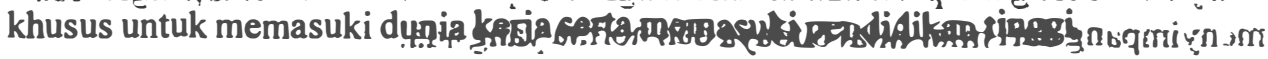


Pembelajaran siswa di sekolah menengah tentunya tidak lepas dari bagaimana perkembangan kejiwaan dan pandangan siswa. Seiring dengan tingkat perkembangan ilmu pengetahuan dan teknologi, khususnya arus informasi yang begitu pesat, baik dari media elektronika ataupun media masa, bahwa masa remaja di sekolah mengalami perubahan yang sangat cepat, arus pendidikan berlangsung dalam setiap sisi kehidupan remaja. Proses pendewasaan kepribadian kehidupan masa remaja semakin cepat berlangsung, dan bahkan sekolah sebagai lembaga formal lamban dalam mengantisipasi perkembangan tersebut. Kompleksitas masalah remaja nampaknya perlu menjadi perhatian guru di sekolah dalam mengantarkan siswa ke pencapaian prestasi yang memusakan. Berkaitan dengan hal ini bahwa guru hendaknya memberikan perhatian terhadapsiswa pada tingkat perkemabangan serta kesulitan yang dihadapinya dalam pembelajaran.

Nampaknya kehidupan siswa di sekolah untuk menciptakan kondisi yang kondusif bagi berlangsungnya pembelajaran merupakan tanggung jawab siswa agar mencapai prestasi yang diharapkan. Upaya ini tentunya dengan membangun motivasi siswa untuk belajar lebih aktif dan giat, karena pada masa ini siswa membutuhkan dorongan yang lebih bagus untuk aktif di sekolah. Hal ini dapat dilakukan dengan menciptakan sistem pembelajaran yang bervarisai seperti melalui studi kelompok, bantuan tutorial.

Untuk meningkatkan motivasi siswa dalam belajar maka diperlukan kurikulum yang relevan dengan realitas kehidupan yang dihadapi siswa. Kurikulum yang tidak menarik sering membuat siswa jenuh dan bosan untuk belajar di kelas Dengan memberikan tanggung jawab belajar mandiri merupakan upaya untuk membangun motivasi belajar seperti pemebelajaran sendiri, penelitian mandiri, pembelajaran kelompok, workhshopsiswa dan sebagainya. Hal ini jelas tidak jauh berboda dengan kondisi siswa sekolah menengah di Indonesia, di mana kehidupan sosial kalangan remaja akan mempengaruhi tingkat motivasi siswa belajar.

Kehidupan remaja yang sudah menampakkan perhatian pada kehidupan sosial dapat tercermin dari kehidupan siswa pada kegiatan organisasi sekolah. Aktifitas siswa baik dalam bentuk kegiatanolah raga, kesenian, kegiatan sosial dan kelompok belajar akan meningkat seiring dengan terus meningkatnya minat siswa untuk berpartisipasi dalam kehidupan sosial. Disamping kondisi ini, pada diri remaja berkembang prilaku penolakan terhadap situasi sosial terkadang yang, khusus berkaitan dengan kehidupan moral yang cenderung terkadang dianggap mengekang dan membatasi dinamikanya.

Kondisi tersebut diatas hendaknya sebagai sarana siswa untuk mematangkan kepribadiannya sehingga ia tumbuh untuk memahami kehidupan sosial yang terjadi di sekelilingnya. Hanya saja peran guru dan orang tua serta masyarakat sangat diperlukan untuk mengontrol perkembangan remaja agar tidak menyimpang dari nilai-nilai budaya dan norma yang ada. 


\section{b. Kurikulum Sekolah Menengah: Penguatan Relevansi}

Kurikulum merupakan suatu rencana pelaksanaan pembelajaran menganai isi dan bahan pelajaran serta sekaligus sebagai pedoman pelaksanaan pendidikan dalam jenjang pendidikan tertentu di sekolah.

Kurikulum memberikan arah dan pedoman yang jelas tentang proses pendidikan mulai dari tujuan, konsep dan arah pembelajaran yang dilakukan pada jenjang sekolah tertentu. Kurikulum yang baik secara jelan mencerminkan bebarapa aspek penting seperti tujuan dan hakekat pendidikan, tujuan dan hakekat kurikulum, asumsi mengenai peserta didik, proses pendidikan dan pengajaran, visi penyusunan kurikulum tentan harapan, tuntutan dan kebutuhan pamakai jasa pendidikan.

Di Amerika bahwa perubahan kurikulum terjadi manakala terjadi peluncuran Sputnik tahun 1957, yangkemudian lahir suatu kurikulum sekolah dengan karakteristik seperti; 1) penekanan pada cirri-ciri disiplin akademik tersendiri seperti biologi, kimia, fisika, geografy, sastra dan bahasa; 2) isi kurikulum meliputi konsep, ide pokok, prisnsip-prinsip utama ; 3 ) bentuk-bentuk penemuan, berpikir induktif, dan cara membimbing siswa untuk menemukan sesuatu secara mandiri; 4) suatu variasi bahan yang digunakan seperti buku paket, film dan laboratorium.

Sampai saat ini bahwa kurikulum pendidikan nasional yang pernah berlaku yaitu kurikulum 1968, kurikulum 1975, kurikulum1984, dan kurikulum 1994 sebagai kurikulum baru bagi perubahan sistem pembelajaran secara menyeluruh. Kurikulum 1968, 1975 dan 1984 masih merupakan kurikulum yang sangat sentralistik dalam semua sistem pembelajaran. Sedangkan setelah UUSPN No. 2. 1989 mulai diberlakukan sekitar tahun 1990, maka sistem pendidikan nasional mengalami perubahan mendasar, yaitu penekanan pada arah pendidikan nasional untuk meningkatkan klualitas sumber daya manusia yang dapat mendukung pembangunan nasional. Terkait dengan ini juga terbitlah PP No.2 Th. 1990 tentang Pendidikan Menengah, yang secara eksplisit memberikan arah pendidikan menengah untuk mempersiapkan siswa pada kehidupan bermasyarakat dan bernegara, memasuki dunia kerja dan melanjutkan ke perguruan tinggi. Sehingga pendidikan menengah terbagi dengan jelas manjadi pendidikan menengah umum dan pendidikan menengah kejuruan.

Itulah sebabnya kemudian lahir kurikulum 1994 yang memberikan bagian penting dari upaya pemerintah untuk meningkatkan kualitas pendidikan nasional. Kurikulum 1994 memberikan tekanan pada penekanan relevansi pendidikan dengan dunia kerja yang tampil melalui program keterkaitan dan kesepadanan (ink and macth) (Dikbud, 1996). Pada tahun 1990-an beberapa kebijakan pendidikan menengah mulai diluncurkan seperti menata kembali pola penjurusan di sekolah menengah; di mana sekolah umum dengan orientasi akademik serta sekolah kejuruan dengan orientasi profesional. Pada sekolah menengah umum bahwa pola penjurusan hanya ada pada saat memasuki kelas III dengan pola IPA, IPS dan Bahasa. 
Sedangkan untuk mempersiapkan siswa untuk memasuki dunia kerja ditempuh melalui jalur sekolah kejuruan, yang secara spesifik memberikan pendidiakan dan pelatihan khusus kepada siswa untuk menjadi tenaga kerja profesional pada tingkat dasar.

Sedangkan kurikulum pada tahun 2002 ini lebih melihat kurikulum sebagai langkah untuk membangun relevansi dan mutu pendidikan yang berkaitan dengan proses out put dan outcome pendidikan. Sehinggga kemunculan Kurikulum Berbasis Kompetensi (KBK) ini merupakan cerminan dari upaya untuk membangun demokratisasi pendidikan, yang melihat keragaman kemampuan peserta didik. Paling tidak ada beberapa asumsi penting yang menyebabkan pentingnya kurikulum berbasis kompetensi, yaitu; 1) memperhatikan kemampuan dan potensi peserta didik yang akan dikembangkan oleh guru, 2) adanya keragaman potensi peserta didik sehingga guru harus dapat membantu siswa menjembatani keragaman itu, 3) pendidikan mengkondisikan lingkungan agar peserta didik dapat mengembangkan potensinya, 4) kurikulum sebagai rencana pembelajaran harus dapat mengembangkan potensipotensi seluruh peserta didik secara optimal.

Nampaknya yang terpenting dalam kurikulum berbasis kompetensi ini adalah berupaya untuk memberikan apresiasi yang tinggi pada potensi-potensi yang dimiliki masing-masing siswa di sekolah. Lebih-lebih pada jenjang sekolah menengah bahwa pesera didik, perkembangan intelektual siswa sudah cukup terarah, kecenderungan potensi yang milikinya telah nampak. Sehinggan diharapkan bahwa secara lebih awal potensi-potensi dan kemampuan pesera didik telah mampu diarahkan dalam menjalankan pendidikan di sekolah.

\section{Daftar Rujukan}

Bacharah, S. B. (Editor). 1990, Education Reform: Making Sense Of It All: USA. Allyen dan Bacon.

Beeby, C.E. 1979. Pendidikan di Indonesia; Penilaian dan Perencanaan Jakarta. LP3ES.

Boediono dan Yulaellawati, 1999. Penyusunan Kurikulm Berbisis Kemampuan Dasar, Jurnal Pendidikan dan Kebudayaan. No.020 Tahun ke-5, Desember 1999

Diknas. 2002. Sistem Pendidikan Tenaga Kependidikan 21(STPK-21) : Jakarta

Jalal. F. dan Supriadi (editor). 2001. Reformasi Pendidikan Dalam Era Otonomi Daerah: Jakrata.Depdiknas-Bappenas-Adicita karya

Jamil, Ibrahim. 1999. Perspektif Tranparansi Global Dalam Kurikulum : Diknas Jur. Pendidikan dan Kebudayaan. No. 019. Tahun ke-5, Oktober 
Husen, T. 1979. The School In Question : New York Oxford University Press

Lurry,L .L dan Alberty, J.E. 1957. Develoving The Core Program : New York The Mcmillan Company

Mantja .W . 1998. Manajemen Pembinaan Profesional Guru Berwawasan Pengembangan SDM; Suatu Kajian Konseptual Historis(Pidato Pengukuhan Guru Besar: Universitas Negeri Malang

Michael. G. Fullan, 1993. The New Meaning Ofeducational Change :New York. Teacher College Press

Murgatroyd. S. dan Morgan. C. 1992. Total Quality Management and School : USA. The Open University

Unruh, G.G. dan Alexender, W.M. 1970. Innovation in Secondary Education: New York Winstin Inc

Rohlen, Thomas, D. 1983. Japan High School :Universty of California

Suyanto. 2001. Guru Yang Profesional dan Efektif. Kompas/16/02/2001.

Suryadi, Ace. 2001. Menyoal Profesi Guru: Kompas/9/03/2001

Seodjiarto. Menuju Pendidikan Yang Relevan dan Bermutu. Jakarta: Balai Pustaka

Tilaar, H.R. 1995. 50 tahun Pembangunan Pendidikan Nasional 1945-1995; Suatu Analisis Kebijakan. Grasindo. Jakarta

UUSPN. No. 2. tahun 1989. 1992. Sinar Grafika. Jakarta

PP. No. 29. Tahun 1990 Tentang Pendidikan Menengah. 1992. Sinar Grafika. Jakarta

Depdiknas. 1990. Menyongsong Penyusunan Kurikulum SMU : Jakarta. Dikdasmen.

Zias, S. Robert. 1976. Curriculum Priciples and Foundation: New York. Harper and Row, Publisher 